\title{
Age estimation accuracy based on Atlas London and Schour-Massler in Tionghoa ethnic children
}

\author{
Icha Artyas Annariswati" ${ }^{*}$, Shintya Rizki Ayu Agitha'
}

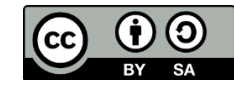

ABSTRACT

Objectives: Age estimation is an important factor in forensic science and needs to be known accurately because it can narrow the search when examining unidentified victims, determine the victim's age at death and is also useful in cases of adulteration of athletes, child guardianship, or to determine whether someone is of legal age. or not according to the law. This study aims to determine individual age estimates based on the London Atlas and Schour-Massler Atlas and compare the accuracy of the two methods.
\end{abstract}

This work is licensed under a Creative Commons Attribution 4.0 which permits use, distribution and reproduction,
provided that the original work is properly cited,
the use is non-commercial and no modifications or a commercial and no moded
adaptations are made.

${ }^{1}$ Department of Dentomaxillofacial Radiology and Odontology Forensic, Faculty of Dentistry, Universitas Hang Tuah, Surabaya, Indonesia, 60111

*Correspondence to:

Icha Artyas Annariswati

囚icha.artyas@hangtuah.ac.id

Received on: June 2021

Revised on: July 2021

Accepted on: August 2021 jrdi.v5i2.704

\section{INTRODUCTION}

Proses identifikasi adalah suatu upaya untuk mendeteksi dan melakukan verifikasi identitas seseorang yang masih hidup maupun yang sudah meninggal berdasarkan karakteristik yang ditemukan pada individu tersebut. ${ }^{1}$ Salah satu parameter dalam identifikasi adalah penentuan estimasi usia. Estimasi usia merupakan faktor penting dalam ilmu forensik dan perlu diketahui secara akurat karena dapat mempersempit pencarian ketika memeriksa korban yang belum teridentifikasi, menentukan usia korban saat kematian dan untuk rekonstruksi profil biologis. ${ }^{2}$ Penentuan estimasi usia tidak hanya dapat digunakan pada korban yang sudah meninggal, namun juga digunakan pada individu yang masih hidup untuk mengklarifikasi masalah kriminal dan sipil. Kasus hukum pidana atau perdata yang memerlukan estimasi usia pada individu hidup, misalnya untuk manajemen usia ketenagakerjaan atau imigrasi yang memerlukan data usia sedangkan dokumen yang diperlukan dalam pengecekan data usia tidak ada. ${ }^{3}$ Penentuan estimasi usia juga berguna pada kasus pemalsuan usia atlet, perwalian anak, atau untuk menentukan
Materials and Methods: 70 panoramic radiographs consisting of 31 boys and 39 girls from Chinese ethnicity in Surabaya, aged 6-13 years (72-156 months). Samples were determined for dental age based on the London Atlas and the Schour-Massler

Atlas. The data that has been obtained is then processed by statistical analysis with SPSS for Windows, with an inclusion level of $p<0.05$.

Results: This study showed that the London Atlas was better and more accurate than the SchourMassler Atlas with a lower mean error and there was no significant difference between the London Atlas dental age estimation and chronological age with $p$ value $=0.426$ in the left region and $p=0.429$ in the right region $(p>0.05)$.

Conclusion: The results obtained from this study indicate that dental development based on the London Atlas and Schour-Massler Atlas can be used as a method to determine the estimated age of children from the range of $6-13$ years in ethnic Chinese.

Keywords: Teeth, age estimation, panoramic, London atlas, Schour-Massler atlas

Cite this article: Annariswati IA, Agitha SRA. Age estimation accuracy based on Atlas London and Schour-Massler in Tionghoa ethnic children. Jurnal Radiologi Dentomaksilofasial Indonesia 2021;5(2)52-9. https://doi.org/10.32793/

seseorang sudah cukup umur atau tidak sesuai aturan undang-undang. Estimasi usia penting dalam pembuktian hukum untuk menentukan individu tersebut dalam kategori anak-anak atau sudah dewasa karena hal ini berkaitan dengan adanya perbedaan proses hukum atau peradilan. ${ }^{4}$

Skeletal dan gigi merupakan bagian tubuh yang paling umum digunakan dalam penentuan estimasi usia. Kematangan skeletal sebagai media estimasi usia memiliki keterbatasan karena hanya dapat menentukan estimasi pada rentang usia tertentu dengan simpangan baku usia yang besar, sedangkan gigi mengalami tahap pertumbuhan dan perkembangan, serta perubahan degeneratif yang terjadi pada usia tertentu, sehingga dapat digunakan sebagai indikator penentuan estimasi usia individu dari sejak usia intrauterin sampai usia dewasa. ${ }^{3}$ Gigi juga merupakan struktur tubuh yang paling keras dan resisten terhadap pengaruh eksternal, serta mengalami perubahan biologis yang paling sedikit sehingga dapat digunakan walaupun tubuh telah mengalami dekomposisi, mutilasi, terbakar, ataupun telah menjadi sisa rangka. Upaya menentukan identitas seseorang melalu gigi dikenal 
dengan ilmu odontologi forensik dimana ilmu tersebut merupakan gabungan antara pengetahuan tentang kedokteran gigi forensik dengan ketrampilan dokter gigi. ${ }^{5}$

Atlas London merupakan salah satu metode yang menggunakan radiografi gigi untuk membantu dalam menganalisis estimasi usia berdasarkan perkembangan gigi. Atlas London dikembangkan oleh Al-Qahtani pada tahun 2008 yang menentukan estimasi usia berdasarkan hubungan tulang alveolar dengan tahapan formasi erupsi gigi dan dapat digunakan mulai usia 28 minggu in-utero hingga 23 tahun. ${ }^{6}$ Metode Atlas London ini memiliki kriteria komprehensif, memiliki bukti dasar, akurat, sensitif, dan mudah digunakan. Penelitian Al-Qahtan pertama kali dilakukan di London dengan menggunakan populasi ras kulit putih dan Banglades yang tinggal di Eropa. Atlas London sering digunakan dalam penelitian di berbagai populasi ras dan etnis karena salah satu di antara faktor yang mempengaruhi pertumbuhan dan perkembangan gigi adalah ras dan etnis. Perbedaan ras dan etnis dapat menyebabkan adanya perbedaan waktu kalsifikasi dan erupsi gigi.

Atlas Schour-Massler juga merupakan metode yang juga sering digunakan dalam penelitian $\mathrm{d} i$ berbagai dan merupakan salah satu metode pertama kali yang dibuat untuk penentuan estimas umur. Atlas ini dikembangan oleh Issac Schour dan Maury Massler pada tahun $1941 .^{8}$ Schour dan massler mengembangkan penelitian Logan dan Kronfeld yang dibuat pada tahun 1933 dengan membuat grafik perkembangan gigi sulung dan gig permanen rahang atas maupun bawah yang digambarkan melalui atlas 21 tahapan perkembangan gigi dari usia 4 bulan hingga 21 tahun. American Dental Association (ADA) secara berkala telah memperbarui atlas ini dan menerbitkannya pada tahun 1982, sehingga memungkinkan untuk membandingkan secara langsung tahap kalsifikasi gigi pada radiografi dengan standar yang telah dibuat Schour dan Massler. Kelebihan dari atlas Schour-Massler adalah non-destruktif karena dapat dilihat dari gambaran radiografi, simpel, dan tidak perlu orang yang terlatih untuk menggunakan metode ini. ${ }^{9}$

Metode yang telah dipublikasikan melaporkan akan ada bias apabila menggunakan satu metode pada sampel kecil dengan usia yang tidak sama. Pada penelitian ini untuk mengurangi hasil yang bias untuk menentukan estimasi usia, maka dilakukan penelitian dengan dua metode yang berbeda yaitu Atlas London dan Schour-Massler. ${ }^{6}$ Berdasarkan uraian diatas, penelitian ini bertujuan untuk menentukan estimasi usia individu dengan dua metode yang berbeda dalam populasi sampel anak etnis Tionghoa di Surabaya dan untuk membandingkan tingkat akurasi dari dua metode tersebut yang akan memungkinkan untuk menyarankan metode yang lebih sessuai yang dapat diterapkan pada populasi anak etnis Tionghoa di Surabaya.

\section{MATERIALS AND METHODS}

Penelitian ini merupakan penelitian analitik observasional dengan mengggunakan populasi sampel radiografi panoramik anak etnis Tionghoa di salah satu tempat praktek dokter gigi spesialis di Surabaya. Sampel yang digunakan sebanyak 70 foto radiografi panoramik yang terdri dari 31 anak laki laki dan 39 anak perempuan. Sampel penelitian diambil pada pasien dengan radiografi panoramik yang memenuhi kriteria antara lain: (1) Radiografi panoramik merupakan milik anak rentang usia 6 13 tahun (72 - 156 bulan) dan untuk kemudahan kalibrasi serta akurasi statistik makan usia dinyatakan dalam bulan; (2) Radiografi panoramik milik pasien yang merupakan anak keturunan etnis Tionghoa hingga 3 generasi di atasnya; (3) Sampel harus mempunyai ketujuh gigi kiri dan kanan bawah lengkap baik sudah erupsi maupun belum erupsi; (4) Sampel merupakan radiograf panoramik dari anak yang tidak memiliki kelainan pertumbuhan, endokrin, gangguan nutrisi, tidak pernah

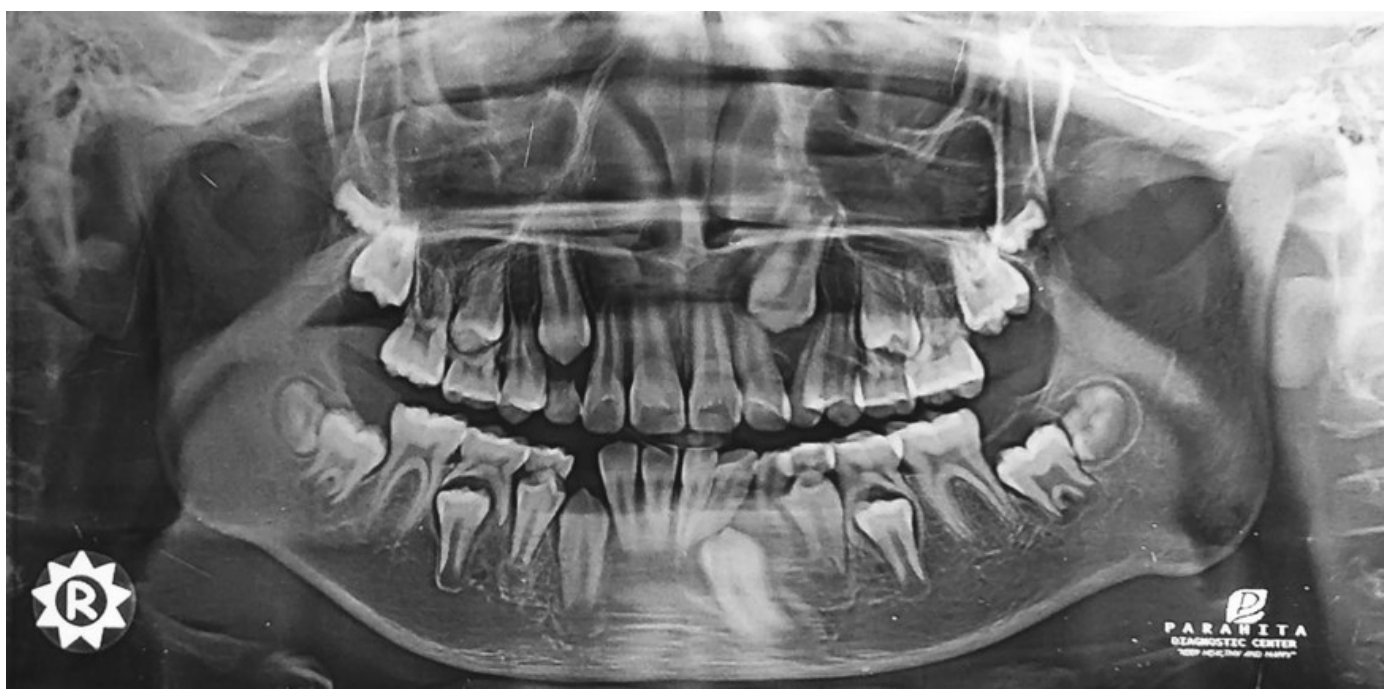




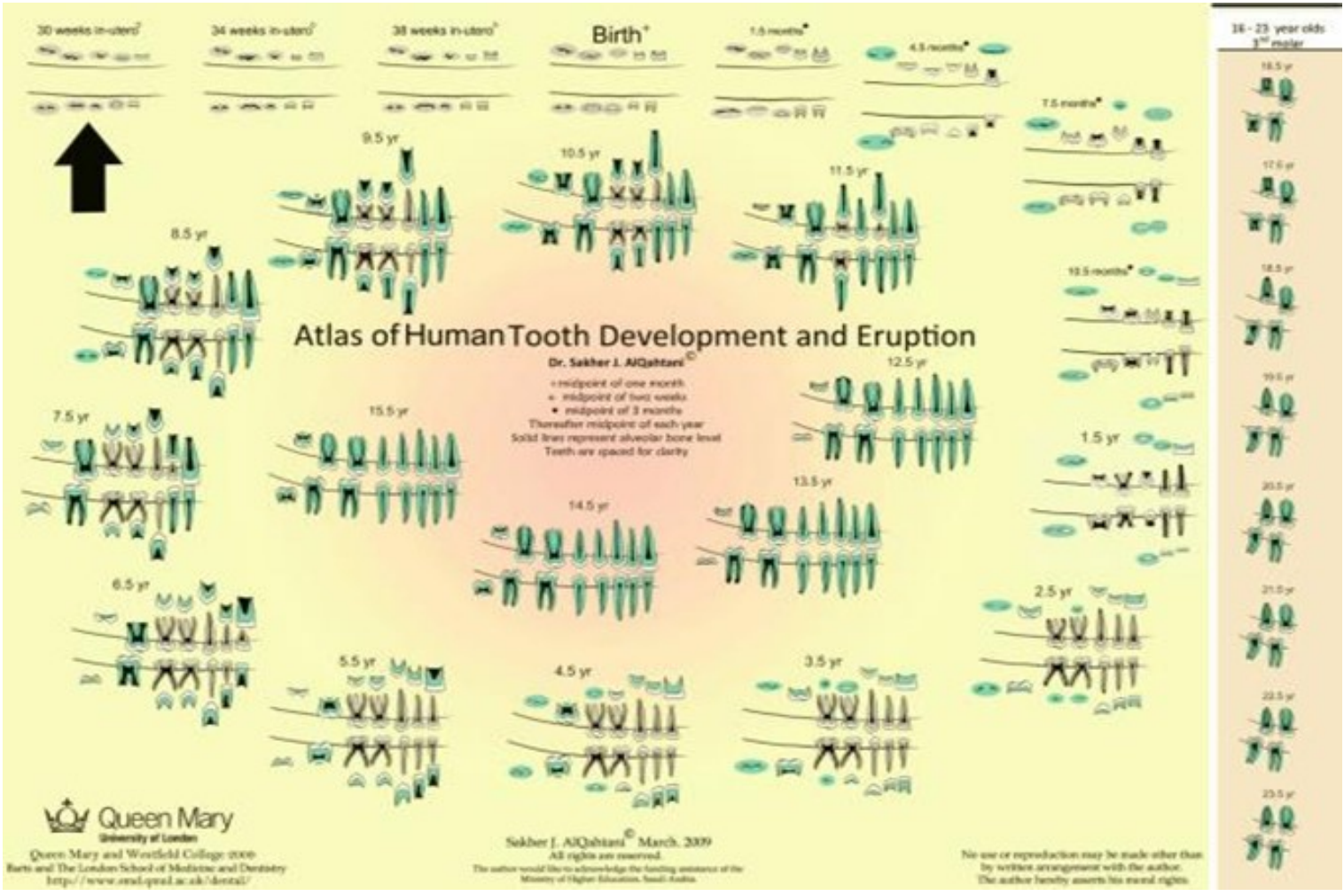

Gambar 2. Tahapan pertumbuhan dan perkembangan gigi berdasarkan Atlas London ${ }^{6}$

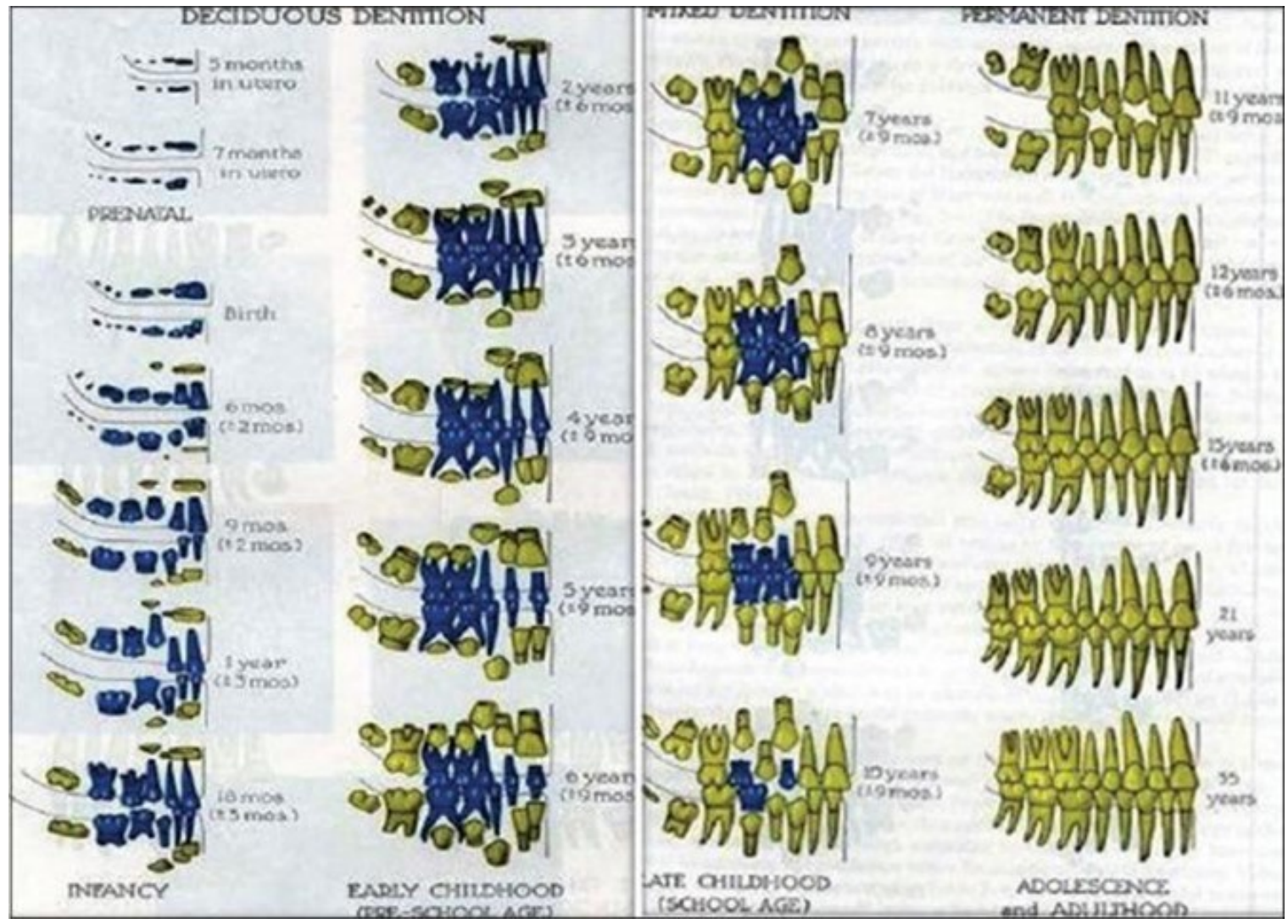

Gambar 3. Tahapan pertumbuhan dan perkembangan gigi berdasarkan metode Schour-Massler ${ }^{8}$

mengalami trauma atau cacat pada daerah mutu radiografi panoramik yang digunakan juga kraniofasial yang dapat mempengaruhi harus baik dan dapat diinterpretasikan. pertumbuhan dan perkembangan gigi; (5) Kualitas Sampel yang telah memenuhi kriteria 
selanjutnya diteliti dengan beberapa tahapan antara lain : (1) Sampel dihitung usia kronologisnya. Usia kronologis yang didapat dengan cara tanggal pembuatan radiografi panoramik dikurangi tanggal lahir yang tertera pada kartu status pasien (usia kronologis = usia tanggal pembuatan orthopantomogram digital - tanggal lahir dan dinyatakan dalam bulan), salah satu contoh sampe yang telah memenuhi kriteria dapat dilihat pada Gambar 1; (2) Menentukan usia dental berdasarkan atlas London dengan cara membandingkan antara tahapan perkembangan gigi yang ada di radiograf panoramik tujuh gigi kiri dan kanan rahang bawah dengan perkembangan gigi berdasarkan Atlas London. Gambaran tahapan perkembangan gigi berdasarkan Atlas London dapat dilihat pada Gambar 2; (3) Menentukan usia dental berdasarkan Atlas Schour-Massler dengan cara membandingkan antara tahapan perkembangan gigi yang ada $\mathrm{d}$ radiograf panoramik tujuh gigi kiri dan kanan rahang bawah dengan perkembangan gig berdasarkan Atlas Schour-Massler. Gambaran tahapan perkembangan gigi berdasarkan metode Schour-Massler dapat dilihat pada Gambar 3; (4) Membandingkan usia kronologis dengan usia denta Atlas London (UAL) dan usia dental Atlas SchourMassler (USM); (5) Data yang telah diperoleh selanjutnya diolah analisis statistik dengan SPSS untuk Windows, dengan level inklusi $p<0,05$.

\section{RESULTS}

\section{UJI KAPPA AGREEMENT}

Sampel penelitian yang telah dianalisis selanjutnya dilakukan uji Kappa Agrement yang didapat dari hasil perhitungan tiap sisi rahang dan menunjukkan hasil yang hampir baik untuk kedua metode. Hasil uji Kappa dilihat pada Tabel 1.

\section{ESTIMASI USIA DAN USIA KRONOLOGIS}

Hasil analisis antara usia kronologis yang didapat dengan estimasi usia Atlas London dan Atlas Schour-Massler pada setiap sisi rahang menunjukkan tidak ada perbedaan signifikan, hasil dapat dilihat pada Tabel 2.

Hasil selanjutnya menunjukkan terdapat perbedaan signifikan antara usia kronologis dengan estimasi usia Schour-Massler (USM) dengan nilai $p=0,031 \quad(p<0,05)$ dan hasil tersebut dapat dilihat pada Tabel 3. Hasil uji T-Test antara usia kronologis dengan estimasi usia atlas London (UAL) menunjukkan tidak ada perbedaan signifikan dengan nilai $p=0,426$ pada regio kiri dan nilai

Tabel 1. Hasil Uji Kappa Agreement

\begin{tabular}{ccc}
\hline & Kanan & Kiri \\
\hline Atlas London & 0,786 & 0,785 \\
Atlas Schour - Massler & 0,842 & 0,848 \\
\hline
\end{tabular}

Tabel 2. Hasil test untuk paired test antara usia kronologis dengan setiap metode

\begin{tabular}{lcccccc}
\hline & \multicolumn{7}{c}{ Pair T - Test } \\
\cline { 2 - 7 } & Mean & SD & $\begin{array}{c}\text { Standard Error } \\
\text { Mean }\end{array}$ & t & df & P value \\
\hline UAL Kiri - USM Kiri & $-3,318$ & 12,774 & 1,195 & $-2,518$ & 69 & 0,001 \\
UAL Kanan - USM Kanan & $-3,324$ & 12,643 & 1,234 & $-2,491$ & 68 & 0,001 \\
\end{tabular}

*Keterangan UAL = Usia Atlas London, USM = Usia Schour-Massler)

Tabel 3. Hasil T-Test antara Usia Kronologis dengan Usia Schour-Massler (USM)

\begin{tabular}{lccccccc}
\hline & \multicolumn{5}{c}{ Pair T - Test } \\
\cline { 2 - 7 } & Mean & SD & $\begin{array}{c}\text { Standard Error } \\
\text { Mean }\end{array}$ & t & df & Palue \\
\hline Usia Kronologis (bulan) - USM Kiri & 3,476 & 13,875 & 1,544 & 1,489 & 69 & 0,031 \\
Usia Kronologis (bulan) - USM Kanan & 3,465 & 13,875 & 1,544 & 1,489 & 69 & 0,031 \\
\hline
\end{tabular}




\begin{tabular}{lcccccc}
\hline & \multicolumn{7}{c}{ Pair T - Test } \\
\cline { 2 - 7 } & Mean & SD & $\begin{array}{c}\text { Standard Error } \\
\text { Mean }\end{array}$ & $\mathbf{t}$ & df & P value \\
\hline Usia Kronologis (bulan) - UAL Kiri & $-0,108$ & 10,319 & 1,075 & $-0,032$ & 69 & 0,426 \\
Usia Kronologis (bulan) - UAL Kanan & $-0,101$ & 10,319 & 1,075 & $-0,036$ & 69 & 0,429 \\
\hline
\end{tabular}

Tabel 5. Mean error antara estimasi usia dan usia kronologis untuk usia Atlas London

\begin{tabular}{lccccc}
\hline & N & Minimum & Maksimum & Mean & Standard Deviasi \\
\cline { 2 - 4 } Atlas London & 70 & $-35,00$ & 24,00 & 0,205 & 10,318 \\
\hline
\end{tabular}

Tabel 6. Mean error antara estimasi usia dan usia kronologis untuk usia Atlas Schour-Massler

\begin{tabular}{lccccc}
\hline & N & Minimum & Maksimum & Mean & Standard Deviasi \\
\cline { 2 - 5 } Atlas Schour-Massler & 70 & $-41,00$ & 29,00 & $-4,492$ & 13,875 \\
\hline
\end{tabular}

Tabel 7. Mean Error antar estimasi usia dan usia kronologis berdasarkan jenis kelamin pada kedua metode

\begin{tabular}{lllllc}
\hline & Jenis kelamin & $\mathbf{N}$ & Mean & $\begin{array}{c}\text { Standard } \\
\text { Deviasi }\end{array}$ & $\begin{array}{c}\text { Standard } \\
\text { Deviasi Error }\end{array}$ \\
\hline Atlas London error & Laki - laki & 31 & 1,876 & 12,862 & 1,0437 \\
Schour-Massler error & Perempuan & 39 & $-1,934$ & 12,651 & 1,1054 \\
& Laki - laki & 31 & $-3,116$ & 15,766 & 2,0764 \\
& Perempuan & 39 & $-2,981$ & 17,398 & 2,1655 \\
\hline
\end{tabular}

$p=0,429$ pada regio kanan $(p>0,05)$ dan hasil tersebut dapat dilihat di Tabel 4.

\section{PERBEDAAN ESTIMASI USIA DENGAN USIA KRONOLOGIS}

Hasil penelitian menunjukkan bahwa usia Atlas London terdapat over-estimasi usia sekitar 0,2 bulan $(p>0,05)$ dan hasilnya dapat dilihat pada Tabel 5, sedangkan usia Schour-Massler terdapat under-estimasi usia sekitar 4,4 bulan $(p>0,05)$ yang hasilnya dapat dilihat pada Tabel 6 . berdasarkan jenis kelamin usia Schour-Massler menunjukkan under-estimasi pada laki - laki maupun perempuan, sedangkan pada usia Atlas London under-estimasi pada perempuan dan over-estimasi pada laki - laki (dapat dilihat pada Tabel 7). Hasill analisis secara keseluruhan dapat disimpulkan bahwa usia Atlas London lebih akurat dan mendekati usia kronologi dibandingkan usia Schour-Massler.

\section{DISCUSSION}

Estimasi usia di bidang forensik merupakan topik yang penting dan sering digunakan untuk proses peradilan atau kasus hukum ketika usia kronologis seseorang tidak diketahui. Metode estimasi usia berdasarkan pertumbuhan dan perkembangan gigi telah diaplikasikan ke berbagai populasi dengan tujuan untuk mengetahui cara yang paling akurat untuk memperkirakan usia dari data yang tersedia dan membantu bahan hukum untuk membuat keputusan akhir. ${ }^{10}$ Literatur ilmiah telah menyediakan sumber informasi dan penelitian tentang berbagai metode, implementasi teknis dan dasar mekanisme tentang estimasi usia melalui gigi atau disebut usia dental. Usia dental merupakan usia yang ditentukan berdasarkan faktor pertumbuhan gigi seperti proses mineralisasi, pelekatan gingiva, perkembangan mahkota dan akar, atau penyempitan ruang pulpa. Perubahan 
degeneratif seperti atrisi gigi atau resorbsi periodontal juga terkait dengan usia dental. ${ }^{11}$

Penetuan estimasi usia dental dapat dilakukan secara klinis, histologi, kimiawi dan radiografi. Radiografi sering digunakan dalam menentukan usia dental karena mempunyai beberapa kelebihan yaitu pembuatan radiograf tergolong mudah dengan biaya yang tidak terlalu mahal, radiogra gigi juga dapat diinterpretasikan dengan cepat terutama apabila korban yang perlu diidentifikas cukup banyak, sehingga korban yang meninggal bisa dengan cepat teridentifikasi sebelum terjad pembusukan lebih lanjut. ${ }^{12}$ Kelebihan lain adalah radiograf gigi tidak memerlukan pencabutan gig seperti analisis histologi atau kimiawi sehingga minim invasiv dan dapat dipakai pada individu yang masih hidup maupun yang meninggal. Radiograf yang dapat digunakan untuk estimasi usia antara lain radiograf periapikal, sefalometri, latera oblique, digital radiografi dan juga CBCT. Penelitian ini menggunakan radiografi panoramik karena radiografi panoramik memiliki gambaran daerah yang jelas dan luas meliputi seluruh gigi yang ada $d$ maksila dan mandibula serta radiograf panoramik juga mudah didapat karena sering digunakan dokter gigi dalam pemeriksaan klinik sehari-hari dan menawarkan harga yang lebih murah. Paparan radiasi panoramik juga minimum dengan dosis radiasi $0,026 \mathrm{msV}^{13}$

Indonesia adalah negara yang terdiri dari berbagai etnis dan setiap etnis memilik karakteristik yang berbeda baik dari segi bahasa, identitas kultural, maupun adat istiadat, tetap terikat oleh suatu kepentingan bersama bersifat formal dalam bentuk sebuah Negara. Salah satu etnis yang lama tinggal di Indonesia adalah etnis Tionghoa. Etnis Tionghoa sudah ada sejak zaman kerajaan-kerajaan di Indonesia yang saat itu jumlahnya masih sedikit, namun saat ini jumlah etnis Tionghoa di Indonesia diperkirakan 5\% dar penduduk Indonesia dan di Surabaya etnis Tionghoa berjumlah $7,5 \%$ dari jumlah penduduk Surabaya serta merupakan etnis terbesar ketiga yang ada $\mathrm{d}$ Surabaya. ${ }^{14}$ Etnis Tionghoa merupakan istilah yang digunakan untuk mengacu pada orang-orang keturunan Tionghoa yang tinggal di Asia Tenggara dan khususnya pada kelompok masyarakat yang berhubungan dengan kebudayaan Tionghoa, sedangkan istilah Tionghoa Indonesia dapat digunakan sebagai seorang Indonesia yang juga memiliki latar belakang etnis Tionghoa. ${ }^{15}$ Etnis Tionghoa mempunyai kelompok sendiri, tidak bercampur dengan masyarakat pribumi yang berasal dari ras protomelayu dan deutromelayu, terutama karena adanya kebijakan wijkenstelsel dan passenstelsel pada zaman kolonial yang melokalisasi pemukiman etnis Tionghoa merupakan titik awal tumbuhnya eksklusivisme di kalangan etnis Tionghoa. ${ }^{16}$

Penelitian ini menunjukkan hasil bahwa Atlas London lebih baik dan lebih akurat dibandingkan dengan Atlas Schour-Massler dengan mean error yang lebih rendah dan tidak terdapat perbedaan signifikan antara estimasi usia dental Atlas London dan usia kronologis dengan nilai $p=0,426$ pada regio kiri dan nilai $p=0,429$ pada regio kanan $(p>0,05)$. Hal tersebut sejalan dengan penelitian McCloe et al. (2017) yang menggunakan Atlas London untuk menentukan estimasi usia pada populasi Hispanik di Amerika serikat yang berusia antara 6-15,99 tahun. Radiografi panoramik sebanyak 322 radiograf terdiri dari 161 laki-laki dan 161 perempuan diteliti dan dibagi menjadi menunjukkan tidak ada perbedaan signifikan antara usia kronologis dengan usia dental baik pada laki-laki maupun perempuan. ${ }^{17}$ Cesario et al. (2016) yang membandingkan antara Atlas London dan Atlas Schour-Massler pada populasi anak dan remaja Portugis di Universitas Lisbon mengemukakan bahwa Atlas London memiliki performa yang lebih baik dalam pengukuran estimasi usia daripada Atlas Schour-Massler. Analisis dilakukan pada 108 radiografi panoramik yang terdiri dari 54 laki-laki dan 54 perempuan dari rentang usia 7-21 tahun menunjukkan hasil perbedaan mean antara Atlas London dan Atlas Schour-Massler masing-masing 0,1389 dan -5,4167 bulan. Atlas Schour-Massler menunjukkan perbedaan yang signifikan antara usia kronologis dengan usia dental dengan nilai $p=0,001 \quad(p<0,05)$ dan Atlas London menunjukkan tidak ada perbedaan yang signifikan dengan nilai $p=0,021$ $(p>0,05){ }^{18}$ Estimasi usia berdasarkan Atlas London juga memilki tingkat akurasi yang lebih tinggi dan lebih mudah diaplikasikan daripada metode Carmerier. Hal tersebut dikemukakan oleh Adriana et al. (2020) yang meneliti 400 radiografi panoramik digital terdiri dari 200 laki-laki dan 200 perempuan dengan usia antara 6-15,99 tahun pada populasi anak Saudi Arabia di Universitas Riyadh. ${ }^{19}$ Penelitian Ghafari et al. (2019) membandingkan antara Atlas London pada 339 anak Iran yang berusia 5-16 tahun. Paired T-test menunjukkan tidak ada perbedaan signifikan antara Atlas London $(p=0,15)$ dengan metode Smith $(p=0,16)$. Kedua metode tersebut menunjukkan tingkat akurasi yang tinggi, namun Atlas London lebih mudah diaplikasikan. ${ }^{20}$

Hasil penelitian menunjukkan bahwa usia Atlas London terdapat over-estimasi usia sekitar 0,2 bulan, sedangkan usia Schour-Massler terdapat under-estimasi usia sekitar 4,4 bulan. Ahmad et al. (2018) menguji akurasi Atlas London di anak-anak Malaysia yang dikategorikan menjadi tiga bagian usia, yaitu 5-5,99 tahun, 10-10,99 tahun, dan 1515,99 tahun. Penelitian menunjukkan terdapat under-estimasi pada kategori usia 10 dan 15 tahun, sedangkan pada grup usia 5 tahun over-estimasi. ${ }^{21}$ Adanya over-estimasi atau under-estimasi ini mungkin dapat disebabkan karena sampel yang diteliti masih kategori anak-anak (6-13 tahun) dimana pada usia tersebut adalah gigi masih dalam pertumbuhan dan perkembangan, berbeda apabila sampel yang diteliti kategori usia dewasa dimana pada usia tersebut perkembnagan gigi mayoritas sudah sampai pada tahap erupsi sempurna sehingga kemungkinan hasil yang didapatkan akan sama. Studi mengenai pola mineralisasi gigi menunjukkan bahwa tahap awal perkembangan gigi hampir sama antara laki-laki dan perempuan, dimorfisme seksual dalam tahap perkembangan gigi terjadi diantara tahap akhir pembentukan mahkota 
dan terus meningkat selama tahap pembentukan akar. Anak perempuan mencapai sebagian besar tahap perkembangan sebelum anak laki - laki, hal ini menunjukkan bahwa pembentukan gigi mengikuti pola pertumbuhan umum dan mungkin dipengaruhi oleh perubahan hormonal. ${ }^{22}$

Berdasarkan jenis kelamin usia Schour-Massler menunjukkan under-estimasi pada laki-laki maupun perempuan, sedangkan pada usia Atlas London under-estimasi pada perempuan dan over-estimasi pada laki-laki (dapat dilihat pada Tabel 7). Perbedaan hasil estimasi usia pada Atlas London antara laki-laki dan perempuan dapat dikarenakan saat pembuatan diagram dari Atlas London, simpulan dari diagram Atlas tersebut merupakan titik tengah dari semua diagram perkembangan gigi yang dihasilkan dari sampel yang digunakan, baik sampel laki-laki atau sampel perempuan. Atlas ini juga memiliki titik tengah dari gabungan diagram laki-laki dan perempuan sehingga dapat digunakan untuk meneliti seseorang yang jenis kelaminnya tidak diketahui. ${ }^{23}$

Metode berbasis atlas memang mudah diaplikasikan dan memiliki tingkat akurasi yang cukup tinggi di berbagai populasi, namun metode berbasis Atlas memilki keterbatasan seperti tidak dapat memberikan gambaran yang mewakili semua kasus dan kegagalan memperbarui untuk memperhitungkan variabilitas dalam waktu tahap formasi dan tahap erupsi gigi. ${ }^{24}$ Keterbatasan lain berhubungan dengan adanya tumpang tindih (overlap) pada tahap maturasi, kurangnya diferensiasi berdasarkan jenis kelamin sehingga dapat menghasilkan tingkat variabilitas yang tinggi terutama pada masa pertengahan anak-anak hingga remaja dan kemungkinan adanya ketidaksepakatan antar pengamat dalam penilaian tahap perkembangan gigi. $^{8}$

\section{CONCLUSION}

Perkembangan gigi berdasarkan Atlas London dan Atlas Schour-Massler dapat digunakan sebagai metode untuk menetukan estimasi usia anak dari rentang 6-13 tahun pada etnis Tionghoa. Hal tersebut dikarenakan tidak ada perbedaan yang signifikan secara statistik antara usia kronologis dan usia dental sehingga metode ini berpotens digunakan untuk kepentingan hukum. Berdasarkan jenis kelamin usia Schour-Massler menunjukkan under-estimasi pada laki-laki maupun perempuan, sedangkan pada usia Atlas London under-estimas pada perempuan dan over-estimasi pada laki-laki, hal ini menunjukkan bahwa atlas dengan grafik universal tidak begitu efisien sebagaimana mestinya dan akan lebih baik apabila ada grafik terpisah untuk setiap jenis kelamin.

\section{ACKNOWLEDGMENTS}

None.

\section{FOOTNOTES}

All authors have no potential conflict of interest to declare for this article. This research was registered and approved by Research Ethics Committee of Faculty of Dental Medicine Universitas Airlangga Surabaya with the registration number of $48 /$ KKEPK.FKG/IV/2016. All procedures conducted were in accordance with the ethical standards.

\section{REFERENCES}

1. Divakar KP. Forensic Odontology: The New Dimension in Dental Analysis. Int J Biomedical Sci. 2017;3(1):1-5.

2. Duangto $P$, Janhom $A$, Prasitwattanaseree $S$, Mahakkanukrauh $P$, lamaroon A. Age Estimation Methods in Forensic Odontology. Journal of Dentistry Indonesia. 2016;23(3):74-80.

3. Smith T, Brownlees L. Age Assessment Practices: A Literature Review \& Annotated Bibliography. United Nations Children's Fund (UNICEF) USA Journal. 2011; 32(2):81-5.

4. Kotecha S. Dental age estimation in children: a review. Forensic Res Criminol Int J. 2016;3(1):264-7.

5. Putri AS, Nehemia B, Soedarsono N. Prakiraan Usia Individu Melalui Pemeriksaan Gigi Untuk Kepentingan Forensik Kedokteran Gigi. Jurnal PDGI. 2013;62(3):55-63.

6. AlQahtani SJ, Hector MP, Liversidge HM. Accuracy of denta age estimation charts: Schour and Massler, Ubelaker and the London Atlas. Am J Phys Anthropol. 2014;154(1):70-8.

7. Rawat G, Kureel K. Dental age estimation in children and adolescents. J Dent Health Oral Disord Ther. 2018:9(4):272-4.

8. Ebrahim E, Rao PK, Chatra L, Shenai P, KM Veena, Prabhu RV et al. Dental Age Estimation Using Schour and Massler Method in South Indian Children Sch. J. App. Med. Sci., 2014; 2(5C):1669 74.

9. Farahyati $S$, Soedarsono $N$, Yuniastuti $M$, Nehemia B. Predicting age in the age group of 16-21 years using toothcoronal index-Benindra method: a comparison with Kvaal and Schour and Massler methods. J. Phys.: Conf. 2018;1073(2):203.

10. Patel PS, Chaudhary AR, Dudhia BB, Bhatia PV, Soni NC, Jani $Y V$. Accuracy of two dental and one skeletal age estimation methods in 6-16 year old Gujarati children. J Forensic Dent Sci. 2015;7(1):18-27.

11. Schmeling A, Dettmeyer R, Rudolf E, Vieth V, Geserick $G$ Forensic age estimation, methods, certainty and the Law, Dtsch. Arztebl. Int. 2016;113(2):44- 50.

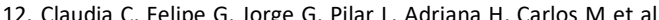
Chronological versus dental age in subjects from 5 to 19 years: a comparative study with forensic implications. Colombia Medica Journal. 2010;41(3):215-23.

13. Panchbhai AS. Dental radiographic indicators, a key to age estimation. Dentomaxillofac Radiol. 2011;40(4):199-212.

14. Pitoyo AJ, Triwahyudi H. Dinamika Perkembangan Etnis Di Indonesia Dalam Konteksi Persatuan Negara. Jurnal Populasi. 2017;25(1):66-9.

15. Christian SA. Identitas Budaya Orang Tionghoa Indonesia. Jurnal Cakrawala Mandarin. 2017;1(1):11-22.

16. Kurniawati Y. Integrasi Etnis Tionghoa di Indonesia : Refleksi Sejarah pada Masa Kolonial Belanda. Factum: Jurnal Sejarah dan Pendidikan Sejarah. 2016;5(1):26-8.

17. McCloe D, Marion I, da Fonseca MA, Colvard M, AlQahtani S. Age estimation of Hispanic children using the London Atlas. Forensic Sci Int. 2018;288:332.e1-332.e6.

18. Cesário C, Santos R, Pestana D, Pereira CP. Medico-Legal Age Estimation in a Sub-adult Portuguese Population: Validation of Atlas Schour and Massler and London. J Civil Legal Sci. 2016;5 (4):196.

19. Correia AM, Barbosa DDS, Alcantara JADS, Oliveira PMDC, Silva PGB, Franco A, Bezerra TP. Performance and comparison of the London Atlas technique and Cameriere's third molar maturity index (I3M) for allocating individuals below or above the threshold of 18 years. Forensic Sci Int. 2020;317:110512.

20. Ghafari R, Ghodousi A, Poordavar E. Comparison of the Accuracy of the London atlas and Smith method in Dental Age estimation in 5-15.99-year-old Iranians using the panoramic view. Int J Legal Med. 2019;133(1):189-95

21. Ismail AF, Othman A, Mustafa NS, Kashmoola MA, Mustafa BE, Yusof MYPM. Accuracy of Different Dental Age Assessment 
Methods to Determine Chronological Age among Malay Children. J. Phys.: Conf. Ser. 2018;1028:012102.

22. Blenkin M, Taylor J. Age estimation charts for a modern Australian population. Forensic Sci Int. 2012;221(1-3):106-12.

23. Rusydiana F, Oscandar F, Sam B. Identifikasi usia berdasarkan metode Al Qahtani melalui radiograf panoramik di RSGM FKG UNPAD. Jurnal Kedokteran Gigi Universitas Padjadjaran. 2016;28(3);166-71.

24. Pavlović S, Palmela Pereira C, Vargas de Sousa Santos RF. Age estimation in Portuguese population: The application of the London atlas of tooth development and eruption. Forensic Sci Int. 2017;272:97-103. 